\title{
Goose barnacles hitchhike on satellite-tracked southern elephant seals
}

\author{
Ryan R. Reisinger • Trevor McIntyre • \\ Marthán N. Bester
}

Received: 16 July 2009 / Revised: 1 September 2009 / Accepted: 1 September 2009

(C) Springer-Verlag 2009

\begin{abstract}
Goose barnacles (Lepas australis) attached to satellite-relay data loggers were carried by three southern elephant seals (Mirounga leonina) from Marion Island. Their movements across the Polar Frontal Zone are presented, providing further evidence that megafauna are potential vectors for the transport of species into the Southern Ocean.
\end{abstract}

Keywords Lepas australis $\cdot$ Southern elephant seal · Species transport $\cdot$ Southern Ocean

Stalked barnacles attach themselves to a wide diversity of substrata including plastics, pumice, wood, macroalgae, tar balls, floating corals, empty Nautilus spp. shells and glass fishing floats (Thiel and Gutow 2005) by means of a long, muscular stalk (Ray and Ciampi 1956). Stalked barnacles have also been reported on fauna such as sea spiders, penguins and seals (Barnes et al. 2004; Setsaas and Bester 2006). Southern elephant seals Mirounga leonina are known to host Conchoderma auritum (South Africa; Best 1971), Lepas sp. (Amsterdam Island; Arnaud 1973) and L. australis (South Georgia; Laws 1953; Arnbom and Lundberg 1995). The goose barnacle L. australis is pelagic with a circumpolar distribution between $30^{\circ} \mathrm{S}$ and $60^{\circ} \mathrm{S}$ (Nilsson-Cantell 1930, 1939; Foster 1978); the distribution of the larval settlement stage, however, is not well known.

The Southern Ocean, bounded by the Polar Frontal Zone (PFZ), is the only marine region without established nonindigenous species, although Thatje and Fuentes (2003)

R. R. Reisinger $(\bowtie) \cdot$ T. McIntyre · M. N. Bester Department of Zoology and Entomology,

Mammal Research Institute, University of Pretoria, Pretoria 0002, South Africa

e-mail: rrreisinger@zoology.up.ac.za found larvae of two genera of decapod crustaceans at the Antarctic Peninsula - the first record of these for the Southern Ocean, likely transported by the intrusion of warmwater rings. Further, Tavares and de Melo (2004) recorded the non-indigenous North Atlantic spider crab Hyas araneus at the same locality and Thatje and Lörz (2005) provided the first record of the lithodid crab Neolithodes brodiei for the Southern Ocean. Such records could reflect recent invasions of the Southern Ocean (Aronson et al. 2007).

While the PFZ—-demarcated to the north by the Subantarctic Front (SAF) and in the south by the Antarctic Polar Front (APF; Belkin and Gordon 1996)-represents an important barrier to species movement (Barnes et al. 2006), a number of vectors do enable the passage of species across the PFZ. For example, Barnes et al. (2004) showed that L. australis seemingly cross the PFZ in large numbers in the South Georgia region, attached to Antarctic fur seals Arctocephalus gazella. Similarly, we report the movements of satellite-tracked southern elephant seals carrying L. australis, providing further evidence that megafauna are a potential vector for transport of species across the PFZ. Such vectors, in combination with global climate change, are likely to abet incursions of non-indigenous species into the Southern Ocean (e.g., Barnes et al. 2006; Aronson et al. 2007).

During December 2008 and January 2009, stalked barnacles were found attached to three satellite-relay data loggers (Sea Mammal Research Unit, Gatty Marine Laboratory, University of St. Andrews) carried by adult female southern elephant seals, which had hauled out to moult at Marion Island $\left(46^{\circ} 54^{\prime} \mathrm{S}, 37^{\circ} 45^{\prime} \mathrm{E}\right)$. Before their return to the Island, the three seals had spent 11,10 and 3 months, respectively at sea after the instruments had been deployed on them at Marion Island. Two to 10 
Fig. 1 a Goose barnacles L. australis attached to the satellite-relay data logger carried by an adult female southern elephant seal M. leonina at Marion Island. b Barnacles attached to the logger assembly carried by an adult female southern elephant seal, October 2007. Photograph by W. Chris Oosthuizen
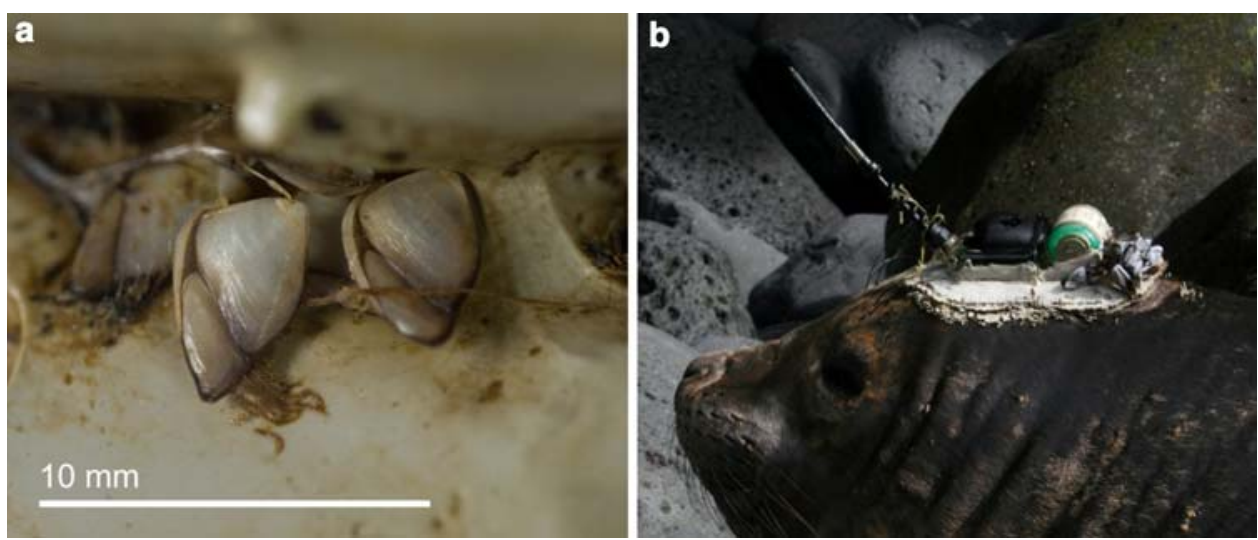

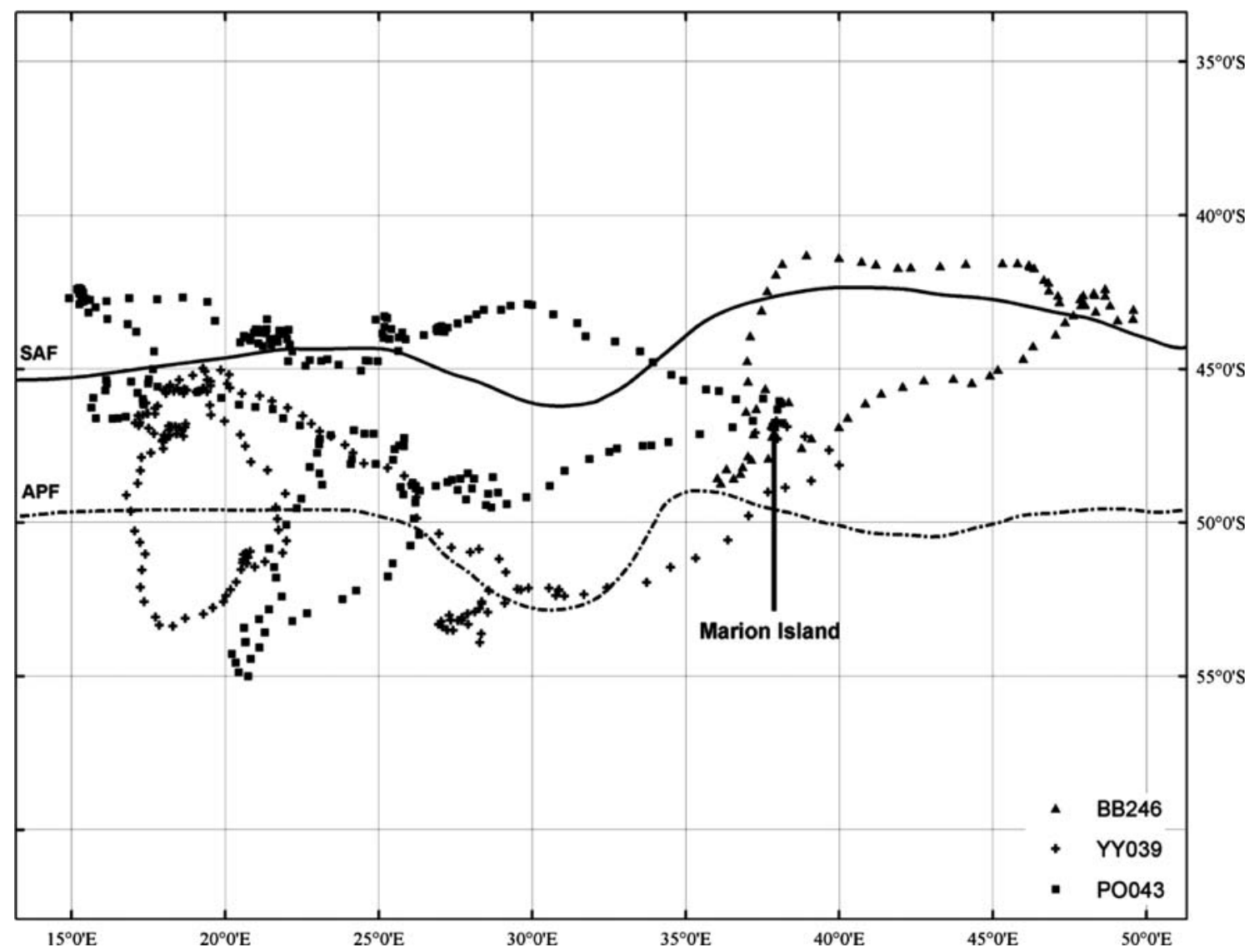

Fig. 2 Mean daily positions of three satellite-tracked adult female southern elephant seals carrying L. australis, mapped with average positions of the $S A F$ (Subantarctic Front) and APF (Antarctic Polar Front), after Belkin and Gordon (1996)

barnacles were found per seal, attached primarily to the surface of the epoxy adhesive used to glue the loggers to the seals' heads (Fig. 1), and also to the loggers themselves. The barnacles were attached mainly to the rear of the loggers, possibly because this posterior zone of turbulent water flow made settling easier and was more suited to nutrition. The specimens were identified as $L$. australis. Despite the 25 years of intensive southern elephant seal monitoring (1983-2008) at Marion Island (de Bruyn et al. 2008), barnacles have only been reported on elephant seals twice previously: in October 2007, attached to the epoxy resin glue of the logger carried by an adult female (Fig. 1), and in September 2006, attached to the pelage on the dorsal midline of an unsexed 1- to 2-year-old animal. However, other cases may have been overlooked or not reported. 
Location data obtained from the loggers via the Argos satellite system were initially filtered using an algorithm based on swimming speed, turning angle and distances between successive locations (Freitas et al. 2008); we chose a maximum speed value for the filter of $3.5 \mathrm{~m} / \mathrm{s}$ (McConnell et al. 1992). After filtering locations based on maximum speed values, locations creating a spike with angles smaller than $15^{\circ}$ and $25^{\circ}$ were removed, if their extensions were in excess of 2,500 and 5,000 m, respectively. All filtering of locations was undertaken in the R environment (R Development Core Team 2007). We then calculated average daily locations and plotted these in ArcGIS (Fig. 2). We defined the SAF in accordance with Belkin and Gordon (1996) and Park et al. (1993). Accordingly, the SAF was located where T-S200 $\mathrm{m}$ ranges of $4-8^{\circ} \mathrm{C}$ and $34.1-34.5$ were present, with axial values of $6^{\circ} \mathrm{C}$ and 34.3. Potential temperature values were calculated and plotted using Ocean Data View software (Schlitzer 2002).

All three animals ranged throughout the PFZ. Two seals (PO043 and BB246) moved north of the SAF during their migrations, while the remaining seal (YY039) appeared to remain within close proximity of the SAF for an extended period. Temperature profiles obtained from the logger carried by the latter seal indicated that the animal did, however, move across the SAF at least once. Both PO043 and YY039 moved south of the APF during their migrations, while BB246 remained in areas north of the APF.

It is unclear where the barnacles originated or how long they were attached; specimens were not aged as their size would have depended on local food availability (which is unknown), and water temperature (cf. Thiel and Gutow 2005). The maximum possible durations of attachment were 11,10 and 3 months, respectively.

Elephant seals thus seem to represent an effective mode of transport across the PFZ. Barnes et al. (2004) suggest that the establishment and spread (after Kolar and Lodge 2001) of barnacles and any hitchhikers they may carry is currently unlikely given the comparatively low water temperatures in the Southern Ocean, yet thermal tolerances of adult and cyprid $L$. australis are unknown (Barnes et al. 2004). Accepted predictions suggest that sea surface temperatures in the Southern Ocean may rise by $2^{\circ} \mathrm{C}$ in the next century (Murphy and Mitchell 1995) and thus current global climate change trends could lower existing barriers to species establishment and spread (Barnes et al. 2006).

Acknowledgments We thank the South African Department of Environmental Affairs and Tourism for providing logistical support within the South African National Antarctic Programme and the Department of Science and Technology (administered through the National Research Foundation) for funding the marine mammal monitoring programme at Marion Island. Chris Oosthuizen and Mashudu Phalanndwa, who deployed the data loggers, and Thomas Mufanadzo, who helped with the recovery of the instrumentation, are thanked for their assistance. We thank Ian Wilkinson and Horst Bornemann for their comments on the manuscript.

\section{References}

Arnaud PM (1973) Le genre Lepas Linné, dans les terres australes et antarctiques françaises (Cirrepedia). Crustaceana 24:157-162

Arnbom T, Lundberg S (1995) Notes on Lepas australis (Cirripedia, Lepadidae) recorded on the skin of southern elephant seal (Mirounga leonina). Crustaceana 68:655-658

Aronson RB, Thatje S, Clarke A, Peck LS, Blake DB, Wilga CD, Seibel BA (2007) Climate change and invasibility of the Antarctic benthos. Annu Rev Ecol Evol S 38:129-154

Barnes DKA, Warren NL, Webb K, Phalan B, Reid K (2004) Polar pedunculate barnacles piggy-back on pycnogona, penguins, pinniped seals and plastics. Mar Ecol Prog Ser 284:305-310

Barnes DKA, Hodgson DA, Convey P, Allen CS, Clarke A (2006) Incursion and excursion of Antarctic biota: past, present and future. Glob Ecol Biogeogr 15:121-142

Belkin IM, Gordon AL (1996) Southern Ocean fronts from the Greenwich meridian to Tasmania. J Geophys Res 101:3675-3696

Best PB (1971) Stalked barnacles Conchoderma auritum on an elephant seal: occurrence of elephant seals on the South African coast. Zool Afr 6:181-185

de Bruyn PJN, Tosh CA, Oosthuizen WC, Phalanndwa MV, Bester MN (2008) Temporary marking of unweaned southern elephant seal (Mirounga leonina L.) pups. S Afr J Wildl Res 38:133-137

Foster BA (1978) The marine fauna of New Zealand: barnacles (Cirripedia: Thoracica). Mem NZ Oceanogr Inst 69:1-160

Freitas C, Lydersen C, Fedak M, Kovacs KM (2008) A simple new algorithm to filter marine mammal Argos locations. Mar Mamm Sci 24:315-325

Kolar CS, Lodge DM (2001) Progress in invasion biology: predicting invaders. Trends Ecol Evol 16:199-204

Laws R (1953) The elephant seal (Mirounga leonina). FIDS Sci Rep $8: 1-62$

McConnell BJ, Chambers C, Fedak MA (1992) Foraging ecology of southern elephant seals in relation to the bathymetry and productivity of the Southern Ocean. Antarct Sci 4:393-398

Murphy JM, Mitchell JFB (1995) Transient response of the Hadley Centre coupled ocean-atmosphere model to increasing carbon dioxide. J Climate 8:36-514

Nilsson-Cantell CA (1930) Thoracic cirripedes collected in 19251927. Discov Rep 2:233-260

Nilsson-Cantell CA (1939) Thoracic cirripedes collected in 19251936. Discov Rep 18:223-238

Park YH, Gamberoni L, Charriaud E (1993) Frontal structure, water masses, and circulation in the Crozet Basin. J Geophys Res 98:12361-12385

Ray C, Ciampi E (1956) The underwater guide to marine life. AS Barnes and Company, New York

R Development Core Team (2007) R: a language and environment for statistical computing. R Foundation for Statistical Computing, Vienna, Austria. http://www.R-project.org

Schlitzer R (2002) Interactive analysis and visualization of geosciences data with Ocean Data View. Comput Geosci 28:1211-1218

Setsaas TH, Bester MN (2006) Goose barnacle (Lepas australis) infestation of the Subantarctic fur seal (Arctocephalus tropicalis). Afr Zool 41:305-307

Tavares M, de Melo GAS (2004) Discovery of the first known benthic invasive species in the Southern Ocean: the North Atlantic spider crab Hyas araneus found in the Antarctic Peninsula. Antarct Sci $16: 129-131$ 
Thatje S, Fuentes V (2003) First record of anomuran and brachyuran larvae (Crustacea: Decapoda) from Antarctic waters. Polar Biol 26:279-282

Thatje S, Lörz AN (2005) First record of lithodid crabs from Antarctic waters off the Balleny Islands. Polar Biol 28:334-337
Thiel M, Gutow L (2005) The ecology of rafting in the marine environment. II. The rafting organisms and community. Oceanogr Mar Biol 43:279-418 